\title{
Site Selection of Local Marketing Cooperatives of Agricultural Crops in West Azerbaijan Province, Iran
}

\author{
Mohammad Jalalzadeh ${ }^{1}$, Seyed Hedayatollah Nouri Zamanabadi ${ }^{1} \&$ Khalil Kalantari $^{2}$ \\ ${ }^{1}$ University of Isfahan, Iran \\ ${ }^{2}$ University of Tehran, Iran \\ Correspondence: Mohammad Jalalzadeh, No. 20, Dehghan Avenue, Alborz Street, Orumiyeh, West Azerbaijan, \\ Iran. E-mail: m.jalalzadeh@iran.ir
}

Received: December 6, 2013 Accepted: January 7, 2014 Online Published: March 24, 2014

doi:10.5539/ijms.v6n2p135 URL: http://dx.doi.org/10.5539/ijms.v6n2p135

\begin{abstract}
Undoubtedly one of the necessities of today's world is the competition with other countries to achieve a balanced position, yet superior in many aspects of economic, social, political and cultural aspects. Based on the statistics, 31.54 percent of the Iran total population lives in rural areas where agriculture is the main source of their income. One of the major problems of agricultural economy in Iran refers to many brokers and intermediaries in the transfer of goods from the producer to the consumer. This reduces the producer's share of the proceeds from the sale of products. Agricultural marketing cooperatives are very important tools to decrease this gap. So in this research have been tried to know and recognize the best places in creating Local Marketing Cooperatives of Agricultural Crops in West Azerbaijan Province, Iran.in this regard, 18 place information layers have been used and finally the best places were known.
\end{abstract}

Keywords: local marketing, cooperatives, agricultural crops, West Azerbaijan, Iran

\section{Introduction}

West Azerbaijan province produces about 30 percent of total apple production in Iran and is allocated to the first position (Statistical Yearbook of Agriculture, 2004). However, despite of having 7 frontier areas and 9 active customs, the main market is affected by the brokers and intermediaries. Based on available statistics, west Azerbaijan with about 13 million dollars exports has the 4th rank of agricultural exporters in Iran. Approximately 16 million dollars of agricultural commodities produced in the West Azerbaijan province have not been exported from formal customs and areas in fact only 42 percent of agricultural export commodity has been exported from the customs Province (Iran exporting Workgroup, 2011). Jalalzadeh (2008), in his research confirmed that more than 60 percent of Apple growers in West Azerbaijan sell their products through intermediaries. According to Najafi (2003), cooperatives by sustaining the farmer income and eliminating the role of intermediaries can help to the rural welfare. The share of marketing cooperatives than total trading in Cyprus and Kuwait were respectively 35 and 80 percent (Alizadeh, 2003). The results of this research can draw an approach for related organizations to design and implement suitable and effective strategies enhancing benefits for both producers and consumers and finally help to sustainable rural and agricultural development.

\section{Literature Review}

\subsection{Agricultural Marketing}

The new concept of marketing was considered since 1960 and the focus shifted from the product to the customer In the past, persuade the potential customers to purchase the product was the Instrument to achieve greater profitability, but in new Paradigm, all elements of the marketing mix (4P) are constituted the instruments to achieve this goal. These elements are: product, price, persuade, channel and location of distribution (Keegan, 2001). Boluriyan Tehrani (2001) believed that the elements of marketing mix are: Product, Place Distribution, Price, Packaging, Public Relations, People, Power and Promotion. Agricultural marketing is a form of marketing that encompasses all goods and services related to the field of agriculture. All these products directly or indirectly support the effort to produce and deliver agricultural products from the farm to the consumer (wiseGEEK, 2013). Sedaghat (2000), in his research about the problems of pistachio marketing recognized that the pistachio marketing is ineffective. Ashrafi et al. (2005) revealed that the share of intermediaries is very high 
in agricultural trades while Mehdipour et al. (2005), emphasizes on high rate of agricultural marketing margin in Iran. Rinarts et al. (2005) and Dong (2007), believed that Lack of effective communication between the producer and the consumer can enhance rate of agricultural marketing margin. Mutual effective relation between the producer and the consumer has mentioned in Mizuno et al. (2008) and B Jama (2008) researches too.

\subsection{Agricultural Marketing Cooperatives}

Production cooperatives are one of the most efficient elements of agricultural production system whose involve many farmers around the country (Saadi, 2007). If we want to have effective cooperatives, we must participate the member farmers in the affairs (Bazrafshan \& hatamshahin, 2010). Agricultural marketing cooperatives are business associations whose principal purpose is to market farm products for producer members (agricultural cooperative service, 1984). Sedaghat (2000) believed that lake of people based organizations and cooperatives are main reasons of pistachio marketing problems. Abbasi (2002), states that cooperatives can help to increase exports. Geravand et al. (2010), in their research showed that the consumers have bought their goods from cooperatives have had more satisfaction rather than the other sectors. B Jama et al. (2008), believed that cooperatives can improve the quality of crops and sustain the supply of goods and its market

\subsection{Site Selection}

The act or instance of site selection comes after analyzing established factors which are known as selection. Site selection refers to the fact of having been chosen. Also, the term refers to the selected location itself as well as the selected real estate (enterprise and economic development glossary, 2013). Parhizkar (1997) believed that, GIS has a greater ability than other models in site selection. Many researchers used than site section in their studies, Faraji et al. (2009), Heidarzadeh (2003), Farhoudi and Zandi (2005) and Manolidiadis (2002) are some examples than many people that use various methods and models of site selection in their scientific works,

\section{Methodology}

The study used a survey design for data collection. All farmers of West Azerbaijan province were included in the study. The sample size was determined as equal to 386 people through Cochran formula and the stratified proportionate random sampling method was used to choose the sample and a questionnaire was designed and employed to gather the required data. Cronbach's alpha computed to measure reliability of the questionnaire and its rate was 0.86 . Face validity of the instrument was determined by related experts. Data were analyzed using descriptive statistics and GIS analysis.

Site selection

Site election has been done by using than GIS model. In this model, some factors and indicators have been chosen and then these factors are weighted in two steps:

- External weight, which is ranking the factors rather than themselves (Table1)

- Internal weight, which is ranking the internal classes of any factor (Table2)
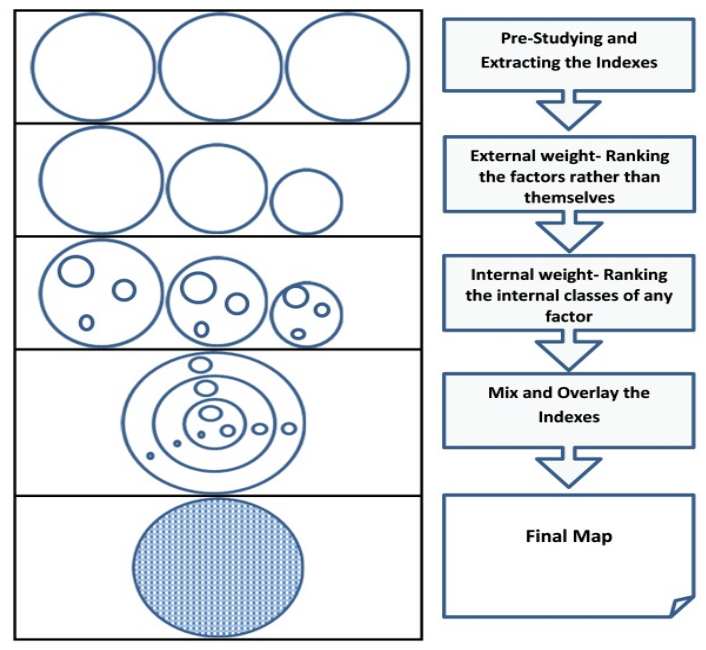

Figure 1. Hierarchy model of site selection by GIS

Source: research team. 


\subsection{Study Area}

West Azerbaijan produces about 30 percent of total apple production in Iran and the first place in this regard is allocated to this province. Despite having several customs and markets with possibility of direct deal between producer and customer, major share of agricultural trade is for big intermediaries. Based on statistics, West Azerbaijan with revenue about 13 million dollars ( 0.59 percent than total of country) from agricultural exports has a very important problem in which only 42 percent of total province exports has done from formal borders and gates and the remaining have been exported from unknown gates (country export workgroup, 2011). Jalalzadeh (2008), believed that about 60 percent of apple farmers in study area use than marketing channels which are under the intermediaries.

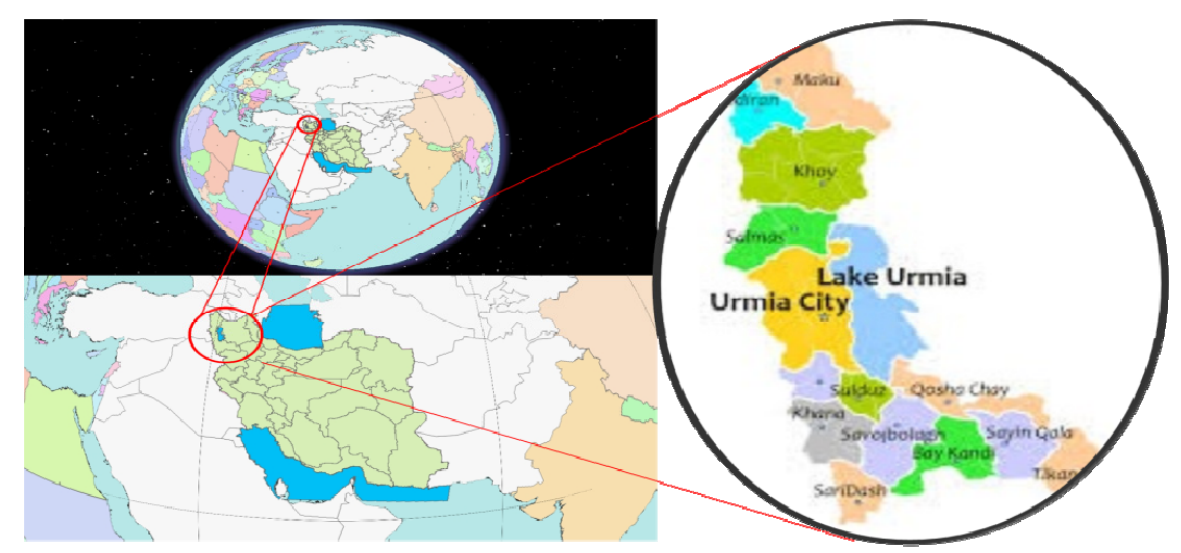

Figure 2. Geographical position of West Azerbaijan

\section{Results and Discussion}

\subsection{Professional and Individual Characteristics of the Apple Farmers}

In total, 366 persons ( 94.8 percent) of the farmers are men and there are merely 20 ( 5.2 percent) female farmers. The average age of the farmers is 49 years and their average farming experience of the respondents is 24 years. Considering the educational level, most of the farmers ( 57.5 percent) have reading \& writing skill. According to the results of this research, the main job of 292 of the respondents ( 75.6 percent) is agriculture and the others have non-agricultural as their main jobs and farming is a part-time work for them (Table1).

Table 1. The individual and professional characteristics of the farmers of West Azerbaijan Province, 2013 ( $n=386$ )

\begin{tabular}{|c|c|c|c|c|c|}
\hline & & Average & Minimum & Maximum & $\begin{array}{l}\text { Standard } \\
\text { deviation }\end{array}$ \\
\hline Age & & 49 & 78 & 23 & 12.318 \\
\hline \multirow[t]{2}{*}{ Farming experience } & & 24 & 1 & 59 & 14.190 \\
\hline & & frequency & percentage & \multicolumn{2}{|c|}{$\begin{array}{l}\text { Cumulative } \\
\text { percentage }\end{array}$} \\
\hline \multirow{3}{*}{ - Gender } & Male & 366 & 94.8 & \multicolumn{2}{|c|}{94.8} \\
\hline & Female & 20 & 5.2 & \multicolumn{2}{|c|}{100} \\
\hline & Illiterate & 45 & 11.7 & \multicolumn{2}{|c|}{11.7} \\
\hline \multirow{3}{*}{ - $\quad$ Educational level } & reading \& writing skill & 222 & 57.5 & \multicolumn{2}{|c|}{69.2} \\
\hline & Diploma & 75 & 19.4 & \multicolumn{2}{|c|}{88.6} \\
\hline & Post- diploma & 44 & 11.4 & \multicolumn{2}{|c|}{100} \\
\hline \multirow[t]{2}{*}{ - $\quad$ Main job } & Agriculture & 292 & 75.6 & \multicolumn{2}{|c|}{75.6} \\
\hline & Non-Agriculture & 94 & 24.4 & \multicolumn{2}{|c|}{100} \\
\hline
\end{tabular}

Source: Research results. 


\subsection{Site Selection}

\subsubsection{Pre-Studying and Extracting the Indexes}

In this step 18 indexes were selected for selecting the best location to establish the local marketing cooperatives which are: Land use, Distance from main city, Distance from Village, Distance from Rural district, Distance from mine, Distance from center of district, slope, soil, Topography, Distance from main roads, Distance from highways and freeways, Distance from natural Faults, Distance from rivers, Distance from Political borders, Climate class, Distance from the landslide, Distance from protected areas, Soil erosion.

4.2.2 External Weight- Ranking the Factors Rather Than Themselves

According to subject of study, the indexes were weighted from 1, 10, 20 to 170 (Table 2).

4.2.3 Internal Weight, Which Is Ranking the Internal Classes of Any Factor

According to importance of any component, the internal components of each index were weighted (Table 3).

4.2.4 Preparing the Layers of Indexes

In this step, the layers of each index have been prepared (Figure 2).

4.2.5 Mix and Overlay the Indexes

The layers prepared in step 4, have been mixed and overlaid and final map of site selection of local marketing cooperatives has been resulted (Figure 3).

Table 2. External weights of index factors

\begin{tabular}{|c|c|c|c|c|c|c|c|}
\hline \multirow[t]{2}{*}{ Index factor } & \multicolumn{3}{|c|}{ Hierarchy of marketing cooperatives } & \multirow{2}{*}{ Factor Index } & \multicolumn{3}{|c|}{ Hierarchy of marketing cooperatives } \\
\hline & Local & Central & Mother & & Local & Central & Mother \\
\hline Land use & & & & Distance from main roads & & & \\
\hline Weight & 100 & 90 & 120 & Weight & 120 & 120 & 140 \\
\hline Distance from main city & & & & $\begin{array}{l}\text { Distance from highways and } \\
\text { freeways }\end{array}$ & & & \\
\hline Weight & 140 & 170 & 160 & Weight & 110 & 110 & 110 \\
\hline Distance from Village & & & & Distance from natural Faults & & & \\
\hline Weight & 170 & 150 & 50 & Weight & 1 & 1 & 1 \\
\hline $\begin{array}{l}\text { Distance from Rural } \\
\text { district }\end{array}$ & & & & Distance from rivers & & & \\
\hline Weight & 160 & 140 & 130 & Weight & 80 & 70 & 60 \\
\hline Distance from mine & & & & Distance from Political borders & & & \\
\hline Weight & 40 & 10 & 80 & Weight & 70 & 60 & 170 \\
\hline $\begin{array}{l}\text { Distance from center of } \\
\text { district }\end{array}$ & & & & Climate class & & & \\
\hline Weight & 130 & 160 & 150 & Weight & 10 & 30 & 20 \\
\hline slope & & & & Distance from the landslide & & & \\
\hline Weight & 50 & 50 & 30 & Weight & 60 & 80 & 90 \\
\hline soil & & & & Distance from protected areas & & & \\
\hline Weight & 150 & 130 & 100 & Weight & 30 & 20 & 10 \\
\hline Topography & & & & Soil erosion & & & \\
\hline Weight & 90 & 100 & 70 & Weight & 20 & 40 & 40 \\
\hline
\end{tabular}


Table 3. Internal weights of index factors

\begin{tabular}{|c|c|c|c|c|c|c|c|c|c|}
\hline \multirow[t]{2}{*}{ Index factor } & \multicolumn{9}{|c|}{ Internal weight } \\
\hline & 10 & 20 & 30 & 40 & 50 & 60 & 70 & & 80 \\
\hline Land use & $\begin{array}{l}\text { Irrigated } \\
\text { agricultural } \\
\text { land }\end{array}$ & $\begin{array}{l}\text { Rain fed } \\
\text { agricultural } \\
\text { land }\end{array}$ & Forest & $\begin{array}{l}\text { Pastures } \\
\text { Desirable }\end{array}$ & $\begin{array}{l}\text { Mountain } \\
\text { pastures }\end{array}$ & Lakes and Golf & \multicolumn{2}{|c|}{$\begin{array}{l}\text { Average } \\
\text { pasture in the } \\
\text { mountains }\end{array}$} & $\begin{array}{l}\text { Saline } \\
\text { plains }\end{array}$ \\
\hline \multirow[t]{2}{*}{ Index factor } & \multicolumn{9}{|c|}{ Internal weight } \\
\hline & 10 & 20 & 30 & 40 & 50 & 60 & & 70 & \\
\hline Topography & $3000-3500 \mathrm{~m}$ & $2500-3000 \mathrm{~m}$ & $500 \mathrm{~m}$ & $2000-2500 \mathrm{~m}$ & $1500-2000 \mathrm{~m}$ & \multicolumn{2}{|c|}{$1000-1500 \mathrm{~m}$} & \multicolumn{2}{|c|}{$500-1000 \mathrm{~m}$} \\
\hline \multirow[t]{2}{*}{ Index factor } & \multicolumn{9}{|c|}{ Internal weight } \\
\hline & 0 & 10 & 20 & 30 & 40 & 50 & & 60 & \\
\hline soil & Water Body & Inceptisols & Aridisols & $\begin{array}{l}\text { Entisols/ } \\
\text { Inceptisols }\end{array}$ & $\begin{array}{l}\text { Entisols/ } \\
\text { Aridisols }\end{array}$ & \multicolumn{2}{|c|}{$\begin{array}{l}\text { Rock Outcrops/ } \\
\text { Inceptisols }\end{array}$} & \multicolumn{2}{|c|}{$\begin{array}{l}\text { Rock Outcrops/ } \\
\text { Entisols }\end{array}$} \\
\hline Soil erosion & VIII & II & III & VII & $\mathrm{VI}$ & $\mathrm{V}$ & & IV & \\
\hline \multirow[t]{2}{*}{ Index factor } & \multicolumn{9}{|c|}{ Internal weight } \\
\hline & 10 & 20 & 30 & 40 & 50 & 60 & & & \\
\hline Climate class & Arid & Very humid & Humid & Semi- humid & Mediterranear & Semi-aric & & & \\
\hline \multirow[t]{2}{*}{ Index factor } & \multicolumn{9}{|c|}{ Internal weight } \\
\hline & 10 & 20 & 30 & 40 & 50 & & & & \\
\hline $\begin{array}{l}\text { Distance from } \\
\text { main city }\end{array}$ & $50000 \mathrm{~m}$ & $30000 \mathrm{~m}$ & $20000 \mathrm{~m}$ & $10000 \mathrm{~m}$ & $5000 \mathrm{~m}$ & & & & \\
\hline $\begin{array}{l}\text { Distance from } \\
\text { Village }\end{array}$ & $5000 \mathrm{~m}$ & $4500 \mathrm{~m}$ & $4000 \mathrm{~m}$ & $3500 \mathrm{~m}$ & $3000 \mathrm{~m}$ & & & & \\
\hline $\begin{array}{l}\text { Distance from } \\
\text { rivers }\end{array}$ & $3000 \mathrm{~m}$ & $5000 \mathrm{~m}$ & $7000 \mathrm{~m}$ & $9000 \mathrm{~m}$ & $11000 \mathrm{~m}$ & & & & \\
\hline $\begin{array}{l}\text { Distance from } \\
\text { natural Faults }\end{array}$ & $10000 \mathrm{~m}$ & $50000 \mathrm{~m}$ & $90000 \mathrm{~m}$ & $130000 \mathrm{~m}$ & $170000 \mathrm{~m}$ & & & & \\
\hline $\begin{array}{l}\text { Distance from } \\
\text { highways and } \\
\text { freeways }\end{array}$ & $170000 \mathrm{~m}$ & $130000 \mathrm{~m}$ & $90000 \mathrm{~m}$ & $50000 \mathrm{~m}$ & $10000 \mathrm{~m}$ & & & & \\
\hline $\begin{array}{l}\text { Distance from } \\
\text { center of district }\end{array}$ & $30000 \mathrm{~m}$ & $25000 \mathrm{~m}$ & $20000 \mathrm{~m}$ & $15000 \mathrm{~m}$ & $10000 \mathrm{~m}$ & & & & \\
\hline $\begin{array}{l}\text { Distance from the } \\
\text { landslide }\end{array}$ & $10000 \mathrm{~m}$ & $20000 \mathrm{~m}$ & $30000 \mathrm{~m}$ & $40000 \mathrm{~m}$ & $50000 \mathrm{~m}$ & & & & \\
\hline $\begin{array}{l}\text { Distance from } \\
\text { protected areas }\end{array}$ & $20000 \mathrm{~m}$ & $40000 \mathrm{~m}$ & $60000 \mathrm{~m}$ & $80000 \mathrm{~m}$ & $100000 \mathrm{~m}$ & & & & \\
\hline Index factor & Internal weic & & & & & & & & \\
\hline & 10 & 20 & 30 & 40 & & & & & \\
\hline $\begin{array}{l}\text { Distance from } \\
\text { Rural district }\end{array}$ & $25000 \mathrm{~m}$ & $20000 \mathrm{~m}$ & $15000 \mathrm{~m}$ & $5000 \mathrm{~m}$ & & & & & \\
\hline $\begin{array}{l}\text { Distance from } \\
\text { mine }\end{array}$ & $5000 \mathrm{~m}$ & $15000 \mathrm{~m}$ & $20000 \mathrm{~m}$ & $25000 \mathrm{~m}$ & & & & & \\
\hline $\begin{array}{l}\text { Distance from } \\
\text { Political borders }\end{array}$ & $200000 \mathrm{~m}$ & $150000 \mathrm{~m}$ & $100000 \mathrm{~m}$ & $50000 \mathrm{~m}$ & & & & & \\
\hline $\begin{array}{l}\text { Distance from } \\
\text { main roads }\end{array}$ & $170000 \mathrm{~m}$ & $130000 \mathrm{~m}$ & $90000 \mathrm{~m}$ & $10000 \mathrm{~m}$ & & & & & \\
\hline Index factor & Internal weig & & & & & & & & \\
\hline & 30 & 40 & 50 & & & & & & \\
\hline slope & $\begin{array}{l}\text { More than } 8 \\
\text { percent }\end{array}$ & $\begin{array}{l}3 \text { to } 8 \\
\text { percent }\end{array}$ & $\begin{array}{l}\text { Less than } 3 \\
\text { percent }\end{array}$ & & & & & & \\
\hline
\end{tabular}




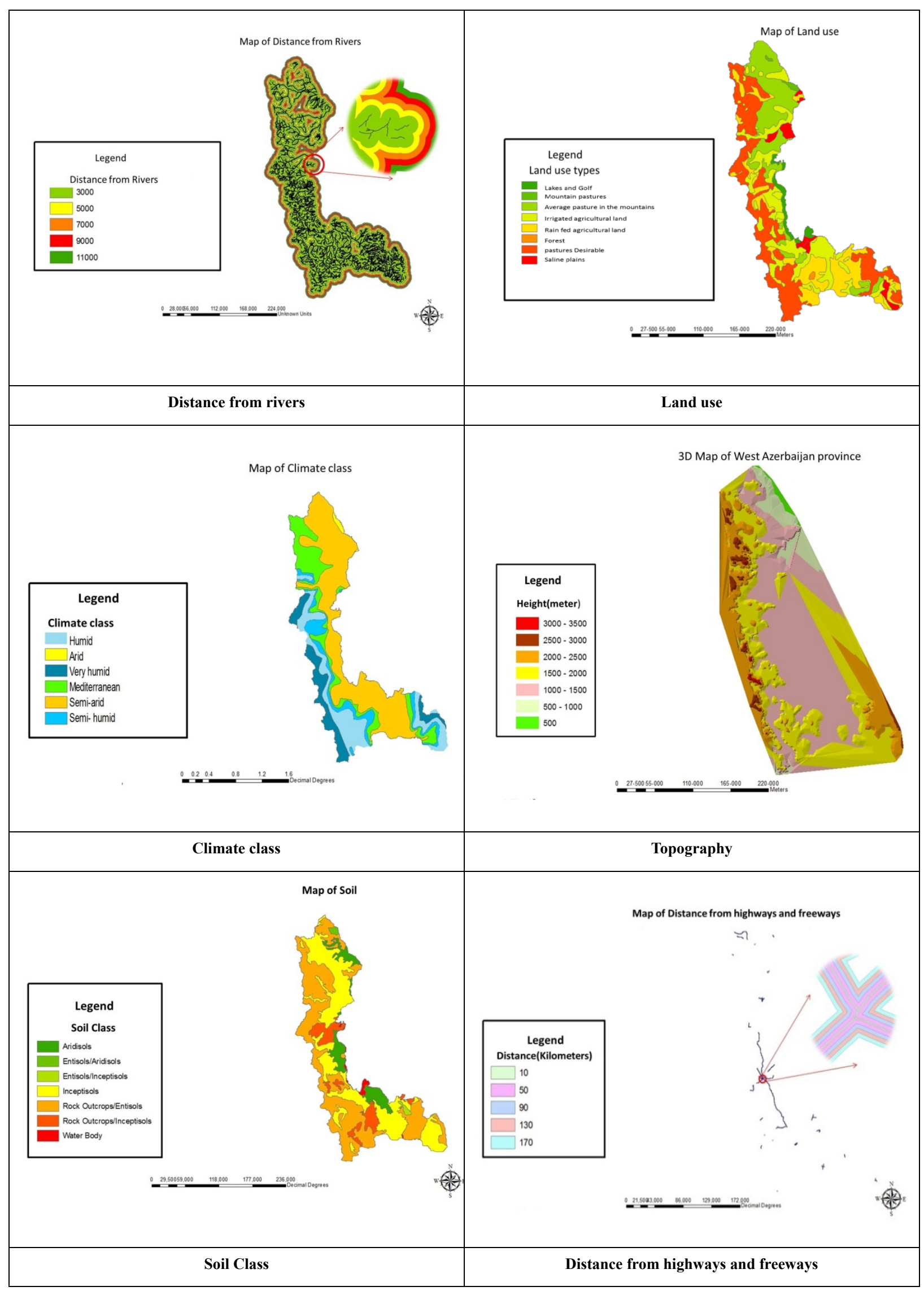




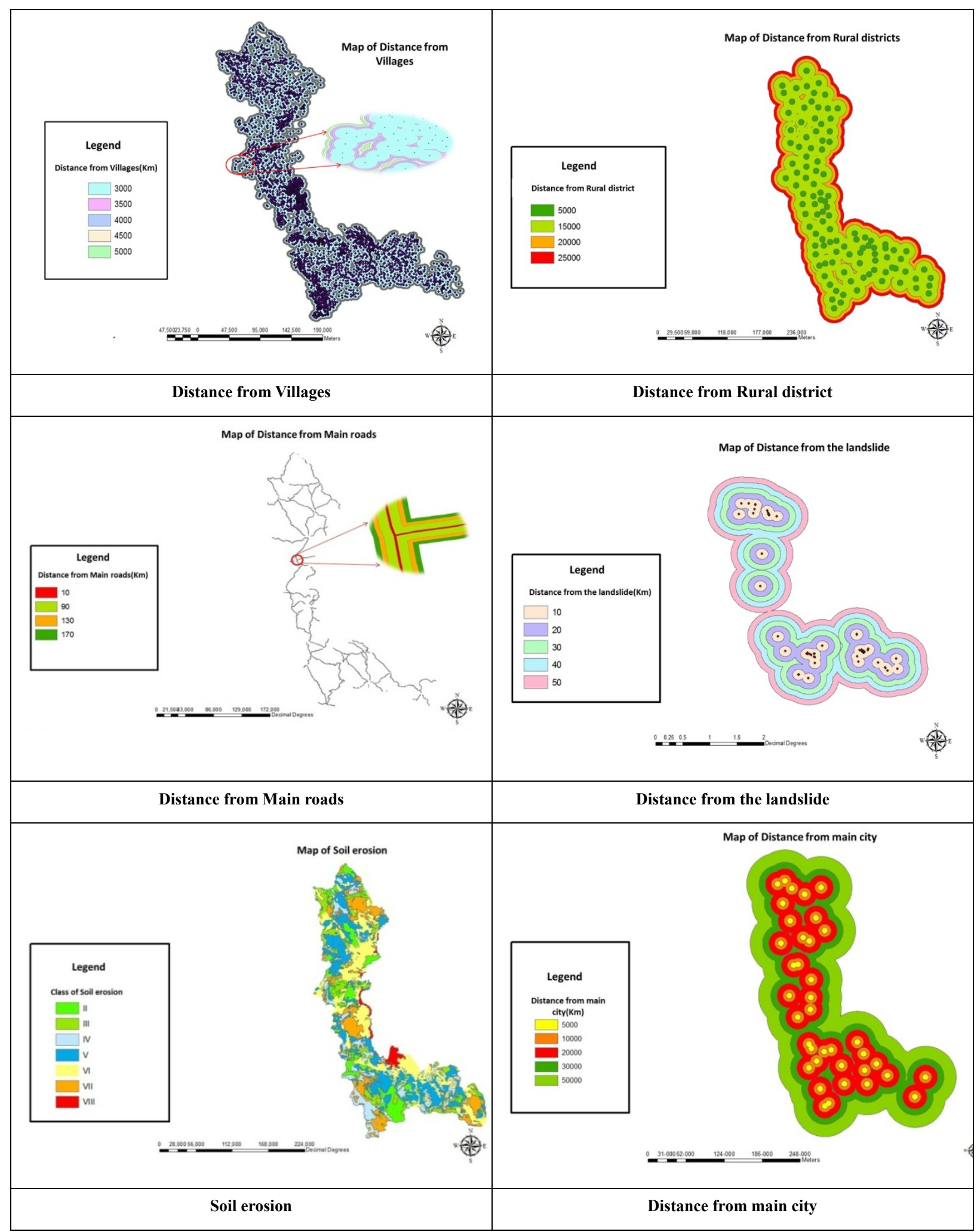




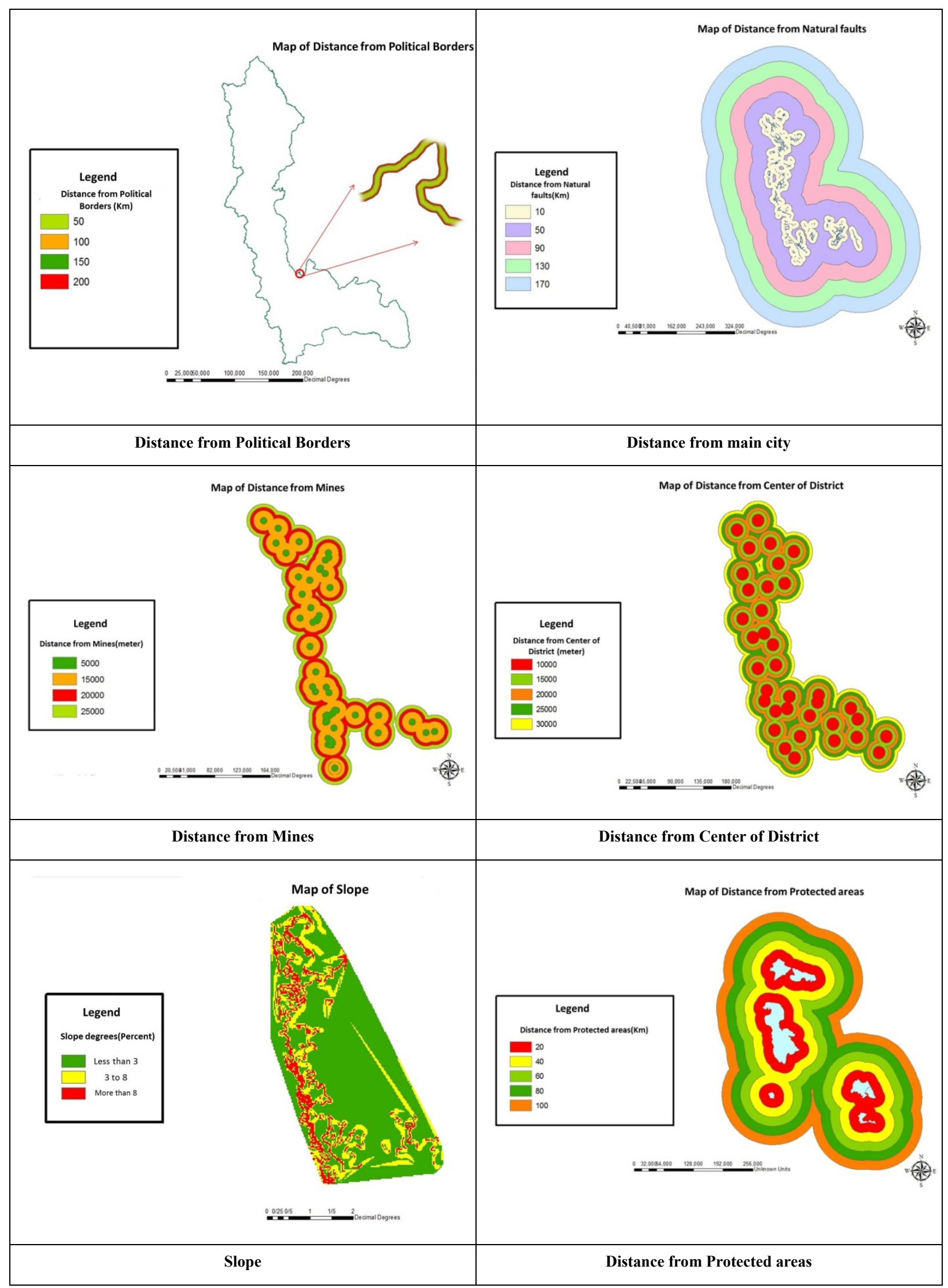

Figure 2. The layers of selected indexes 

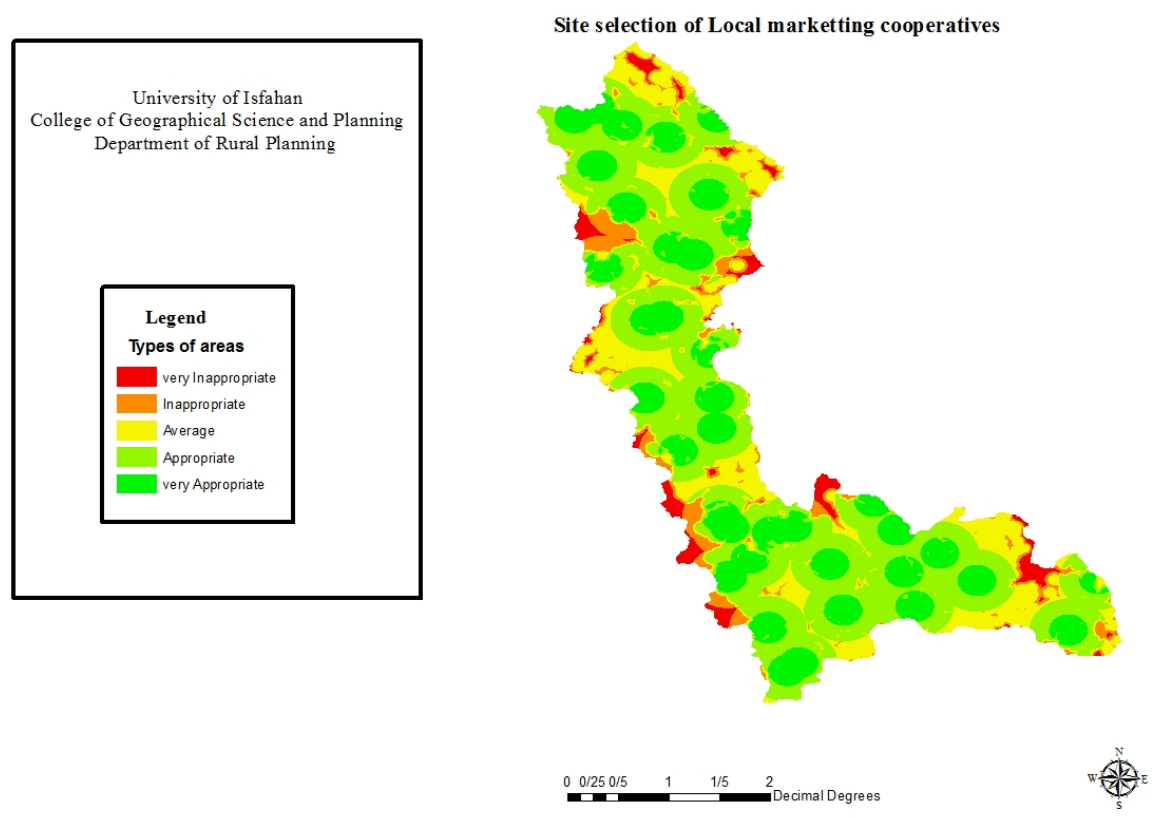

Figure 3. Final map of site selection of local marketing cooperatives

Based on final results and according to the viewpoints of related experts, West Azerbaijan has been divided to 5 types of area to establish the local marketing cooperatives. Findings of final map (Figure 3) revealed that frequent locations are suitable (appropriate and very appropriate). So by according to another requirement the local marketing cooperatives can establish at the favorable locations where comprehensive conditions have in this regard.

\section{Acknowledgements}

The authors gratefully acknowledge the Department of rural planning, University of Isfahan, Iran for equipment support. The authors also thank of Agricultural extension organization experts of West Azerbaijan province for cooperation with authors.

\section{References}

Abbasi, M. (2002). Cooperative sector, the need for global markets. Journal of Cooperation, 133, 4.

Alizadeh, G. H. (2003). Cooperation, WTO and the need for IT applications in cooperatives. Journal of Cooperation, 148, 8-12

Ashrafi, M., Sadrolashrafi, M., \& Karbasi, A. (2005). Investigating the marketing margin of grapes and raisins in Iran. Journal of Commercial Bulletin, 35, 213-238.

Bazrafshan, J., \& Hatam, S. H. (2010). Pathology of Iranian rural cooperatives. Proceedings of the Fourth International Congress of the Islamic World Geographers.

Boluriyan, T. M. (2001). Marketing and market management. Publication of institute of commercial studies and researches, Tehran, Iran.

Cooperative Service. (1984). Farmer cooperative statistics. U S D A., Cooperative Info. Rep. No. 27.

Dong, W., Swain, S., \& Berger, P. (2007). The role of channel quality in customer equity management. Journal of Business Research, 60. http://dx.doi.org/10.1016/j.jbusres.2007.05.005

Enterprise and economic development glossary. (2013). Retrieved from http://www.sitelocationassistance.com/search/dictionary/s/site_selection.htm

Export workgroup of Iran. (2011). Monitoring the provincial foreign trade. Publication of Trade Promotion Organization of Iran, Ministry of Industry, Mine and Trade.

Faraji, H., Karimzadeh, H., Sahneh, B., \& Kouhestani, H. (2009). Modelling a siteselection of landfill in rural areas by GIS (Case study: rural areas of bostan abad county). Journal of geography and planning, 27, 
$17-45$.

Farhoodi, R., Habibi, K., \& Zandi, B. P. (2005). Site selection of Municipal solid waste landfill location by using Fuzzy Logic in GIS desktop (case study: Sanandaj county, Iran). Journal of Beautiful Arts, 33.

Geravand, A., Noorayi, M., \& Saei, I. (2010). The impact of marketing mix on purchasing decisions and customer satisfaction in production cooperatives of Kouhdasht county. Journal of Cooperation, 3, 69-87.

Heidarzadeh, N. (2003). Criteria of Site selection of Municipal solid waste landfill location. Publication of organization of Municipalities of the country.

Jalalzadeh, M. (2008). Investigation and Analyzing the Components of Improvement of Gardens Management in Orumieh County. Master Thesis in Rural Development, Tehran University, Karaj.

Jama, B., Mohamed, A., Mulatya, J., \& Njui, A. (2008). Comparing the "Big Five": A framework for the sustainable management of indigenous fruit trees in the dry lands of East and Central Africa. Ecological in Dicators, 8 .

Keegan, W. (1936). Management of global marketing. Publication of cultural research office, Tehran, Iran.

Manoliadis, O., Baronos, A., \& Tsolas, I. (2001). A two level multicreteria DSS for landfall site selection. Environmental Protection and Ecology, 45-49.

Mehdipoor, E., Sadrolashrafi, M., \& Karbasi, A. (2005). Investigating the Marketing of Potato Product in Iran. Journal of Agricultural science.

Mizuno, M., Saji, A., Sumita, U., \& Suzuki, H. (2008). Optimal threshold analysis of segmentation methods for identifying target customers. European Journal of Operational Research. http://dx.doi.org/10.1016/j.ejor.2007.01.038

Najafi. (2003). Understanding the status of agricultural marketing in rural cooperatives. Research project.

Parhizkar, A. (1997). Offering a suitable model for site selection urban service centers with research about models and urban GIS. PhD Thesis. Tarbiat modarres University, Tehran.

Reinartz, W., Thomas, J., \& Kumar, V. (2005). Balancing acquisition and retention resources to maximize customer profitability. $J$ Mark, 69(1). http://dx.doi.org/10.1509/jmkg.69.1.63.55511

Saadi, H. (2007). Pathology of Agricultural production cooperatives. Journal of Jahad.

Sedaghat, R. (2000). Economic evaluation of pistachio marketing in Fars province. Journal of Agricultural economy and Development, 32, 273-290.

Statistical Center of Iran. (2004). Annual agricultural yearbook. Retrieved from http://www.amar.sci.org.ir

WiseGeek. (2013). Retrieved from http://www.wisegeek.com/what-is-agricultural-marketing.htm

\section{Copyrights}

Copyright for this article is retained by the author(s), with first publication rights granted to the journal.

This is an open-access article distributed under the terms and conditions of the Creative Commons Attribution license (http://creativecommons.org/licenses/by/3.0/). 